\title{
LEGAL PROTECTION FOR NURSES IN PROVIDING HEALTH SERVICES IN HOSPITALS
}

\author{
Sakir Sila*, Achmad Ruslan**, Slamet Sampurno S. ${ }^{* *}$, Harustiati A. Moein ${ }^{* * *}$ \\ *Doctoral Student, Graduate School, Hasanuddin University, Indonesia \\ ${ }^{* *}$ Professor, Faculty of Law, Hasanuddin University, Indonesia \\ ${ }^{* * *}$ Senior Lecturer, Faculty of Law, Hasanuddin University, Indonesia
}

\begin{abstract}
Legal protection of nurses in carrying out their profession to provide health services in hospitals, is a very basic thing to maximize the duties of nurses in serving clients / communities. The legal protection has been regulated in various laws and regulations, namely the Health Law, Hospital Law, Health Worker Law, Nursing Law and Minister of Health of the Republic of Indonesia Regulation Number 4 Year 2018 concerning Patient Obligations and Hospital Obligations. However, this legislation only regulates the legal protection of nurses in civil cases, where the actions of nurses are considered detrimental to the client, in criminal cases there is no clear Government policy regarding legal protection for nurses, especially for nurses who have not been proven guilty but have been put in custody because it is suspected of making a mistake or negligence in nursing practice.
\end{abstract}

Keywords: health services, hospitals, legal protection, nurses.

DOI: $10.7176 / \mathrm{JLPG} / 83-18$

Publication date:March $31^{\text {st }} 2019$

\section{Introduction}

Health is a natural thing for humanity in living their lives. Being healthy is an investment that is highly coveted by both the people and the State. Therefore, the aspect of health services is fundamental in carrying out national development. This good desire is in line with the national goal of advancing the general welfare stated in the opening of the 1945 Constitution of the Republic of Indonesia.

Government cooperation in each developing country (without denying developed countries) is needed, because in addition to the empirical conditions or the ability of different countries to fulfill facilities that are the main driving factors for citizens' health, also the government's political will to improve/maintain quality the life of its citizens is very necessary (Nilawati Adam, 2015:78). In Indonesia, the people's need for health is regulated in Article $28 \mathrm{H}$ paragraph (1) of the 1945 Constitution of the Republic of Indonesia which reads, "Every person has the right to live in physical and spiritual prosperity, to live and get a good and healthy environment and entitled to health services". This statement in our constitution clearly emphasizes that the State is obliged to guarantee full citizens/residents to be able to fulfill their basic needs in the form of health.

Nurses are the most health workers in the provision of health services in Indonesia. Health Human Resources data utilized in the Health Service Facilities (Fasilitas Pelayanan Kesehatan/Fasyankes) throughout the territory of the Republic of Indonesia, shows the number of nurses as many as 345,371 people from 841,090 people in total health workers (http://www.bppsdmk.kemkes.go.id, accessed on August 4, 2018), or 41.06\% of the total number of health workers (there are 13 types), including medical personnel (doctors) who work in health care facilities in Indonesia.

Julianus Ake (2002: 5), said that in essence, nursing is a profession that is devoted to humanity, meaning that the nursing profession prioritizes the health of society above its own interests. Nursing service is a form of service that is humanistic by using a holistic approach, based on knowledge and nursing tips that refers to the standard of nursing services and use the nursing code of ethics as the main guidance in carrying out nursing services.

A nurse who runs a nursing profession by taking medical action cannot work alone, because he needs someone who has other disciplines in helping his work (Nilawati Adam, 2015:213). Nursing services provided by nurses to the community (clients) in the effort of health services, such as health services provided by other health workers, are one of the aspects regulated by law. The law that governs nurses is a part of health law called the nursing law. This is said by J. Guwandi (2004:13), if it is seen in the scope of health law, then it includes:

1. Medical law, 
2. Nurse law,

3. Hospital law,

4. Law on environmental pollution,

5. Law of waste (from industry, household, etc.),

6. Law of pollution (noise, smoke, dust, odor, poisonous gas),

7. Law of equipment that uses X-rays (cobalt, nuclear),

8. Work safety law,

9. And other regulations that have direct links that can affect human health

The existence of nurses in the implementation of health services in Indonesia by lex specialist is regulated in Law of the Republic of Indonesia No. 38 Year 2014 on Nursing (Nursing Law). However, other laws such as Law of the Republic of Indonesia No. 29 Year 2004 on Medical Practice (Medical Practice Law), Law of the Republic of Indonesia No. 36 Year 2009 on Health (Health Law), Law of the Republic of Indonesia No. 44 Year 2009 on Hospitals (Hospital Law) and Law of the Republic of Indonesia No. 36 Year 2014 on Health Workers (Health Workers Law), also mentioned/regulated nurses even though they were not specifically.

In carrying out nursing practice, nurses have several tasks. The duties of nurses are contained in Article 29 of the Nursing Law, namely as nursing care providers, counselors for clients, nursing service managers, nursing researchers, executing tasks based on delegation of authority, and/or implementing tasks within certain limitations. These tasks can be carried out jointly or individually and must be carried out responsibly and accountably.

In Article 18 and 19 of the Nursing Law, it is stated that before practicing nurses are required to have a Registration Certificate (Surat Tanda Registrasi/STR) and a Nurse Practice License (Surat Izin Praktik Perawat/SIPP), both for nurses who practice in health care facilities and those who practice independently. Both types of licensing are the main requirements that must be owned by nurses if they want to practice nursing in Indonesia. The obligation to have STR and SIPP, in carrying out nursing practices should be obeyed by nurses as citizens who obey the law, but this requirement is sometimes ignored.

This condition was felt by Harsono Eko Saputro (Nurse) in Bekasi who was sentenced to five months in prison and detained by the Panel of Judges of the Banyuwangi District Court through Decision No. 52/Pid.Sus/2018/PN Byw, dated February 26, 2018. Legally proven and convincing guilty of committing a criminal offense without permission to circulate pharmaceutical preparations and/or medical devices that do not have distribution permits, violating Article 197 of the Health Law, and sentenced to three months in prison and a fine of one million rupiah and stipulating that the defendant be detained. The police arrested Harsono for opening an independent nursing practice without permission and was deemed to circulate/provide hard-list medicines to his clients without marketing authorization from the Government.

The Harsono case shows and also becomes a lesson for everyone, that there are many legal loopholes in the Health Law and other laws and regulations, which can be used by communities/law enforcement officials to bring nurses to the legal sphere and have been proven to imprison nurses. Although based on the facts revealed at the trial, the activities of nurses who practice without permits (SIPP) in cases that afflict nurses Harsono, there is no action at all that harms the client, and even helps the surrounding community in maintaining health (curing their illness). Nurses who practice only because they do not have an SIPP that does not harm the client and is accepted by the surrounding community, should be given more appropriate warning or other administrative sanctions so that they can immediately take care of their SIPP and do not need to be criminalized.

The quality of health services in various fields makes health workers no longer out of the SOP that have been determined, even because of advances in technology and information, a health worker is also required to master the field (technology and information) in order to adapt to existing era standards (Nilawati Adam and Maria Ana Liwa, 2018:104). A hospital is a form of health care facility that has a very important task. Hospitals, as one form of public service carry out the duty of government to carry out activities in order to fulfill basic human rights to obtain health services (E.W. Yustina, 2012:1). Along with the development and demands of the people who increasingly want better health services. Based on the mandate of the Law on Hospitals, the Hospital Accreditation Commission (Komisi Akreditasi Rumah Sakit/KARS) adopted the 2012 Version of the Hospital Accreditation Standard, which was followed by the National Standard for Hospital Accreditation edition 1 (Standar Nasional Akreditasi Rumah Sakit/SNARS 1), which took effect in January 2018, as an assessment instrument in hospital accreditation in Indonesia. The safety of patients (clients), when setting foot in a hospital in order to get treatment/care is an element that is a major concern in the assessment of these two standards. 
In carrying out an independent function in the hospital and in-home care, the nurse has a direct relationship with the patient (client). Juridically, there are two aspects of nurse and client relations, namely a direct relationship that raises a nursing agreement between the client and the nurse, and the direct relationship that is the doctor's delegation. Nurses in carrying out nursing services, in principle, can make an agreement with the client about the nursing actions to be performed (M. Fakih, 2012:47). Carrying out nursing practices that are not in accordance with the code of ethics, nursing service standards, professional standards and Standard Operating Procedures (SOP) have the potential to cause errors or negligence. In the search of the author, there are a number of cases involving nurses related to health services that are given to clients in hospitals, namely:

1. The case of the nurse helping the surgeon at Nyai Ageng Pinatih Gresik Hospital

Three doctors and three nurses were named suspects of suspected malpractice against M. Gathfan Habibi (5 years old) during tumor spindle cell surgery at Mother and Child Hospital (Rumah Sakit Ibu dan Anak/RSIA) Nyai Ageng Pinatih. They were snared by Medical Practice Law with threats over five years. Two Habibi operating doctors (Dr. Yanuar Syam and Dr. Diki Tampubolon) and drg. Ahmad Zayadi as Director of RSIA Nyai Ageng Pinatih. Meanwhile from nurses, two from Regional Public Hospital (Rumah Sakit Umum Daerah/RSUD) Ibnu Sina (Masrikan and Fitos Vidianto) and a nurse at RSIA Nyai Ageng Pinatih (Putra Bayu Herlambang). The three nurses suspect Putra Bayu Herlambang, Masrikan and Fitos Vidianto were snared Article 76 of Law of the Republic of Indonesia No. 29 Year 2004 junto Article 359 and Article 361 of the Penal Code junto Article 55 Paragraph (1) part 1 of the Penal Code. The three nurse nurses were threatened with five years in prison (sindonews.com online, April 2, 2015).

The day after undergoing a surgical operation, January 3, 2015 at 3:00 West Indonesia Time (Waktu Indonesia Barat/WIB) Habibi was referred to the RSUD Ibnu Sina, Gresik because Habibi's hands were blue. Until the next 71 days, the treatment did not improve and died later, Saturday, March 14, 2015 (Berita Satu. Online, April 8, 2015)

2. Cases of Blood Transfusion Errors performed by Nurses named Mutia at PT Arun Lokseumawe Hospital

Musliadi Salidin, a biological child from Badriah Daud (56 years old), a malpractice victim mistaken for a blood transfusion at PT Arun Hospital, said he was very disappointed with the judge's decision. Because the verdict was handed down by the judge to the suspect, Cut Meutia, the hospital nurse was only eight months in prison. (Aceh Journal National Network, online, May 9, 2017).

The nurse was directly involved in the blood transfusion process in a patient named Badriah Daud, a resident of Geulumpang Sulu Timur, Dewantara Subdistrict, North Aceh, until the patient suffered convulsions, coma, even had to undergo dialysis, as reported by his family (Serambinews. online, April 7, 2016).

3. The nurse named Indri Astuti installed an infusion of children at Setya Novanto

The nurse incident at the Medika Permata Hijau Hospital installing infusion needles for children to Setya Novanto when hunted down by the Corruption Eradication Commission (Komisi Pemberantasan Korupsi/KPK) should not have happened. Chairman of the Semarang National Nurses Association (Persatuan Perawat Nasional Indonesia/PPNI) in Central Java, Bambang Purwantoro, said nurses should be independent and work professionally in accordance with the nursing code of ethics (Kompas.com, online, March 16, 2018).

While in the hospital, according to the prosecutor, doctor Bimanesh ordered a nurse named Indri Astuti to pretend to put an infus to Novanto. "The defendant requested that the infusion be just taped", said prosecutor Moch Takdir Suhan. However, according to the prosecutor, Indri continued to carry out the infusion. However, Indri uses small needles measuring 24 which are commonly used for children (kompas.com, online, March 8, 2018)

The summary of the news shows that nurses who work in hospitals do not escape mistakes that can be considered as detrimental to their clients/families. Errors made due to carrying out the self-action (independent function), also because it works to assist the doctor or work on the doctor's instructions (dependent function). This alleged error is usually responded to by the client/family by reporting the nurse as an ethical violation, civil suit, and/or report to the police (criminal). Based on these phenomena and facts, the problems discussed in this paper are What is the legal protection for nurses from the government/legislations? and What is the legal protection for nurses from hospitals? 


\section{Research Method}

This research is a normative-empirical type, namely the object of study examining primary and secondary legal materials, and also non-legal materials as well as field research. The approach used is the legislative, conceptual, historical, and case approach

\section{Results and Discussion}

\section{A. Legal Protection for Nurses from Government/Legislations}

Health as part of human rights which at the domestic level of a country becomes a human right for every citizen must be fulfilled by the state, both the right to get good health services, as well as to open the widest access to existing health facilities or services (Nilawati Adam, 2017:19). Nurses as a health profession that has an object of service that is in the form of assistance given to clients, healthy or sick, in carrying out activities that play a role in health or recovery (or to face death calmly), due to physical and mental weaknesses, limited knowledge, and lack of willingness towards the ability to carry out activities independently. The goal of this nursing service is the client, who has the feeling and mind in receiving a service. In health services, other names of clients are patients.

Nurses must always adhere to the nurse's code of ethics based on Pancasila and the 1945 Constitution of the Republic of Indonesia (Kadarudin and Nilawati Adam, 2012:76). Nursing service is an activity that can only be given by those who go through special education, get a diploma, and have permission given by the Government to carry out nursing services. In the nurse-client relationship, both parties have an equal position, because every action that the nurse will take to the client, must require the involvement of the client in the form of agreement. The nurse is not possible to take an action against the client without being allowed by the client/family, except in an emergency, where the client is not able to give his consent for example in an unconscious state, heart attack, etc., where there is no family to accompany the client the obligation for nurses under the law to provide help/health services.

In general, patients who come to the care unit are sudden and unplanned. This causes the families of patients to come with faces that are full of various stressors, namely fear of death, uncertainty of results, worries about the cost of care, situations and decisions between life and death, and various kinds of calamities that are likely to occur (Nilawati Adam, 2012:93).

No doubt as an ordinary human being, a nurse in carrying out her profession provides nursing services in a hospital, sometimes doing an action that is considered detrimental to the client/family. The feeling of dissatisfaction of the client/ family can result in reporting to nurses, both law enforcement (criminal/civil) and to violations of ethics or professional discipline. This condition requires the existence of a legal protection system for nurses, in carrying out their profession to provide health/nursing services. Both nurses work in health centers, communities, health clinics, independent practices and those who work in hospitals.

Maria Theresia Geme in Salim HS and ES Nurbaya (2013:262) argues that legal protection is "Relating to the actions of the State to do something by (enacting State law exclusively) with the aim of providing assurance of the rights of a person or group of people". According to Hadjon (1987:2), two types of legal protection are distinguished for the people, namely: preventive legal protection and repressive legal protection. In preventive legal protection, the people are given the opportunity to raise objections (inspraak) or their opinions before a government decision gets a definite form. Thus, preventive legal protection aims to prevent the occurrence of disputes while on the contrary repressive legal protection aims to resolve disputes.

Based on the theory of legal protection above, in terms of preventive legal protection for nurses, the Government and the House of Representatives (Dewan Perwakilan Rakyat/DPR) have made and ratified several laws concerning legal protection for nurses in carrying out their profession in Indonesia. These laws include: Law of the Republic of Indonesia No. 36 Year 2009 on Health (Health Law), Law of the Republic of Indonesia No. 44 Year 2009 on Hospitals (Hospital Law), Law of the Republic of Indonesia No. 36 Year 2014 on Health Workers (Health Workers Law) and Law of the Republic of Indonesia No. 38 Year 2014 on Nursing (Nursing Law). In the discussion of the Nursing Law, the Government and the House of Representatives also involved nurse professional organizations namely the PPNI until they passed into law.

The legal protection of nurses in carrying out their profession in providing health services in Indonesia, including those who provide services in hospitals is regulated in: first, the Health Law, which is found in Article 
27 Paragraph (1) and Article 29. Article 27 Paragraph (1) states health (including nurses) has the right to receive compensation and legal protection in carrying out their duties in accordance with their profession, and Article 29, affirms that in the event that health workers are suspected of negligence in carrying out their profession, such negligence must be resolved first through mediation.

Mediation is a process of dispute resolution between two or more parties through negotiations or a method of consensus with the help of neutral parties who do not have the authority to decide (Takdir Rahmadi, 2017:12). Of course, the mediation process between health personnel and the patient (client) or family is facilitated by an unauthorized party (mediator), aiming for both parties to agree to resolve disputes in consensus, family, or peace and do not need to be continued by law enforcement or litigation.

Second, the Hospital Law also contains provisions on legal protection for nurses, contained in Article 29 Paragraph (1) letter s and Article 46. In Article 29 Paragraph (1) letter s states that each hospital is obliged to protect and provide legal assistance to all hospital officers in carrying out their duties. In addition, Article 46 states that the hospital is legally responsible for all losses incurred due to negligence committed by health workers in the hospital.

Third, in the Law on Health Workers it is stated in Article 57 letter a and Article 78. In Article 57 letter a, it is stated that Health Workers in carrying out the practice have the right to obtain legal protection as long as they carry out their duties in accordance with Professional Standards, Professional Service Standards, and Standard Operating Procedures. Furthermore, in Article 78 it is stated, in the event that the Health Worker is suspected of negligence in carrying out his profession, which causes harm to the recipient of health services, disputes arising from such negligence must be resolved first through the settlement of disputes outside the court in accordance with the provisions of legislation.

Settlement of disputes outside the court that can be taken is through negotiation, mediation or conciliation depending on the situation and conditions that enable consensus building or peace between health personnel and patients (clients). Fourth, in the Nursing Law there are also norms governing legal protection for nurses in conducting nursing services/care, namely Article 36 letter a, which states that nurses in carrying out nursing practices have the right to obtain legal protection as long as carrying out their duties in accordance with service standards, professional standards, standard operational procedures, and provisions of legislation.

The four laws and regulations have contained very strict norms regarding the guarantee of legal protection provided by the State (Government) to the health work profession including nurses while carrying out nursing services in accordance with service standards, professional standards, standard operating procedures and regulatory provisions current regulation. Apart from that, in carrying out nursing practice in the hospital, nurses are required to obtain approval from the client/family if they will take nursing action, and after that the nurse is also obliged to document the nursing activities in the client's medical record. Both of these include evidence that can free the nurse from legal entanglement, if there is an alleged error/negligence in the nursing practice done to the client.

Therefore, according to the author, that in carrying out his profession to provide health/nursing services to clients in hospitals, nurses have been protected by various types of devices namely; legislation, approval of nursing actions, documentation of nursing activities/actions, service standards, professional standards, nurse professional code of ethics and SOP. So that nurses are obliged to work in accordance with these devices if they do not want to be ensnared by the law. This legal protection means that as long as nurses carry out their nursing practices in accordance with service standards, professional standards, standard operating procedures and applicable laws and regulations, then they may not be arbitrarily arrested or imprisoned by law enforcement or required to compensate for no reason at all they allegedly made a mistake or negligence with the client. Everything must go through a legal process first. With this legal protection, it is expected to provide peace to nurses in working to provide health/nursing services to clients (patients) in hospitals and in other nursing practices.

However, in terms of legal regulation, there are still eight provisions contained in the Articles of Nursing Law, which must be further elaborated in the Regulation of the Minister of Health (Permenkes), which until now has not been promulgated. The eight things that must be regulated in the Permenkes, it is very important to realize the legal protection of nurses, because it relates to nurses' activities in carrying out their profession related to nurse identity, prerequisites for Indonesian graduates permits for nurses to carry out nursing practices, areas where nursing services are carried out, duties and limits of nurses' authority in practice, boundaries or types that nurses must keep secret about their clients, emergencies that allow nurses to act 
outside/exceed their authority limits, and supervise nurses in carrying out its activities providing nursing services to the public by the Government and related institutions.

The provisions above should have been arranged, because the Nursing Law has been passed more than 4 (four), namely on October 17, 2014, but until now it has not been realized, even though it is very necessary in ensuring good and safe nursing practice. Nevertheless, based on the author's interview with Ani Nurhayati (Head of Subdivision of Health Human Resources Regulation and Health Development Research Bureau of Law and Organization of the Ministry of Health of the Republic of Indonesia) on December 5, 2018 stated that:

"The Ministry of Health has compiled Permenkes regarding the 8 (eight) matters which are combined in one Minister of Health Regulation, namely Minister of Health Regulation concerning the Implementation of Nursing Law, the discussion has been completed from a verbal process which will be harmonized at the Ministry of Justice and Human Rights will then be downloaded. The discussion process also involves elements from PPNI"

The explanation from Ani Nurhayati, is enough to give hope that in the not too distant future, the Minister of Health Regulation which regulates eight things that are very important in preventive legal protection for nurses will soon be released.

Based on the explanation, from the four laws (Health Law, Hospital Law, Health Workers Law and Nursing Law), which concerns legal protection for health workers/nurses including nurses in hospitals, if analyzed more deeply, it seems only regulating legal protection of health personnel (nurses) in terms of civil law only, which is concerned with compensation suffered by the client, because of allegations of negligence committed by nurses who will be resolved through mediation or resolution of disputes outside of other courts.

There is still something missing from the legislation, namely if the nurse is suspected of carrying out negligence or an error reported by the client and/or his family to law enforcement, of course the nurse should also be given legal protection by the State until the judge's decision is legally binding. Because the nurse could have been named a suspect (detained) by law enforcement even though he was not necessarily guilty. The nurse should have been suspected of making a mistake/negligence, accompanied by a legal advisor (advocate) financed by the Government/hospital, both at the level of examination, investigation and trial. What's more, if the nurse has performed health/nursing services in accordance with service standards, professional standards, professional code of ethics, SOP, and applicable laws and regulations.

This condition was also acknowledged by Yanti Herman (Head of Subdivision of Health Service Regulations, Law and Organization Bureau of the Ministry of Health of the Republic of Indonesia) based on the results of an interview with the author on December 5, 2018, which said "There is no plan for the Ministry of Health to make Minister of Health Regulation on Legal Aid for Health Workers (Nurses) if there are legal problems in carrying out their profession to provide health services in health care facilities in Indonesia".

What was stated by Yanti Herman above, illustrates that if the nurse makes a mistake/negligence in performing health services that cause harm to the client/family, and is reported criminally by the client/family to law enforcement, the nurse cannot hope for help an advocate from a health care facility where he works, so he must face his own criminal case that befell him, even though legally it has not been proven guilty, namely the decision of a judge who has permanent legal force. Nevertheless, Yanti Herman further revealed that the Law and Organization Bureau of Ministry of Health of the Republic of Indonesia was always ready to aid health workers with legal problems in terms of:

a. Assist in mediation efforts.

b. Give assistance in the form of readiness to become an expert witness if needed in court.

c. Accompanying the lawyer by preparing the materials needed.

d. But all of that is done if there is a request from the health personnel concerned

\section{B. Legal Protection for Nurses from Hospitals}

As mentioned in the previous section, that in the Hospital Law there are provisions regarding legal protection for nurses (hospital staff) contained in Article 29 Paragraph (1) letter s and Article 46. In the article it is stated that each hospital is obliged to protect and provide legal assistance for all hospital officers in carrying out their duties. In addition, in Article 46, it is stated that the hospital is legally responsible for all losses incurred due to negligence committed by health workers in the hospital. 
The above provisions become orders and obligations for each hospital to provide legal protection for hospital staff or health personnel (including nurses) in carrying out their duties to provide health services to clients/communities in hospitals. Hospitals are also obliged to overcome all the losses of patients (clients) due to negligence committed by nurses. For losses incurred by nurses to clients because of the intentional element according to Article 46 of this Hospital Law not included in the hospital's dependents. So that it can be concluded is the responsibility of the nurse who made a mistake.

Further explanation about legal protection that must be given by the hospital to nurses (hospital staff), is contained in Minister of Health Regulation Number 4 Year 2018 concerning Hospital Obligations and Obligations of Patients. Article 23 of the Minister of Health states that the obligation of hospitals to protect and provide legal assistance to all hospital officers in carrying out their duties is carried out by providing legal assistance, facilitating mediation and judicial processes, providing legal advocacy, aiding in medical dispute resolution, and allocating budgets for funding legal processes and compensation.

In connection with legal protection activities for nurses (hospital staff), based on the interview of the author with the legal department in 2 (two) hospitals in Makassar consisting of Government and Private hospitals in January 2019, it was mentioned that for hospitals that under the Ministry of Health, the following efforts are carried out:

a. If there are nurses who experience legal issues related to mistakes/negligence of nurses both criminal and civil, will be coordinated with the Legal, Organizational and Public Relations Section at the Directorate General of Health Services of the Ministry of Health of the Republic of Indonesia.

b. In preparing the Annual Work Plan (Rencana Kerja Tahunan/RKT) a budget is provided for legal assistance for health workers (including nurses) who experience legal problems.

c. Collaborating with the High Prosecutor in the context of legal protection for health workers.

d. The hospital directly carries out/provides legal assistance but is sought first through mediation efforts

In private hospitals activities carried out in the context of legal protection for nurses if they experience legal problems in providing nursing/health services at the hospital namely:

a. Initially they will receive complaints from patients (clients).

b. Identifying the alleged mistake/negligence of the nurse.

c. Strive for mediation between clients and nurses.

d. Mediation and negotiations carried out by involving the Nursing Committee/Medical Committee.

e. If the agreement is successful between the two parties, a memorandum of understanding will be made.

f. If you have not succeeded in the first stage, mediation/renegotiation will be carried out.

g. If mediation/negotiation does not produce results, the hospital will provide legal assistance both non-litigation and litigation.

Legal assistance provided by hospitals under the Ministry of Health was also confirmed by Yuliana Sriwahyuni (Head Office of the Directorate General of Health Services of Ministry of Health of the Republic of Indonesia) interview by the author, November 27, 2018) stating:

"The policy of the Directorate General of Health Services of Ministry of Health of the Republic of Indonesia in legal protection for nurses (health workers) in carrying out their profession in hospitals refers to the Health Law, Hospital Law, Health Workers Law and Nursing Law because all health workers are entitled to legal assistance in carry out his profession to provide health services at the hospital".

For this reason, the steps taken by the Directorate General of Health Services of Ministry of Health of the Republic of Indonesia are:

a. Require all hospitals under the Ministry of Health of the Republic of Indonesia to report to the Director General of Health Services if experiencing legal problems including issues related to actions taken by health workers in providing health services both criminal and civil matters. 
b. The Directorate General of Health Services of the Ministry of Health of the Republic of Indonesia, represented by the Department of Justice and Human Rights, will collaborate with the hospitals that have legal problems to mediate with those who report/claim/subpoena.

c. If there is no agreement in the mediation effort, legal assistance will be provided in the form of assistance/preparing materials needed in the police/prosecutor's office in a criminal case.

d. In a civil case, a defense will be conducted in court, where the Defense Team from the Department of Law and Hospital will be provided with a letter of assignment from the Directorate General of Health Services.

Nevertheless, based on the recognition of the three parties above, there has never been a case involving nurses who entered the legal domain they handled. What ever happened was a legal problem involving other health workers, so they did not have experience in dealing with the problem of errors/negligence caused by nurses in providing health services in hospitals. In order to find out the nurse's understanding of hospital protection to nurses when carrying out negligence in carrying out their duties, the authors distributed questionnaires to 100 nurses in three major hospitals in Makassar in January 2019 with the following results:

\begin{tabular}{|c|l|c|c|}
\hline No. & \multicolumn{1}{|c|}{ Question } & Yes & No \\
\hline 1. & $\begin{array}{l}\text { Do you understand that the hospital is obliged to protect and } \\
\text { provide legal assistance to nurses in carrying out their } \\
\text { profession? }\end{array}$ & $\begin{array}{c}95 \\
(95 \%)\end{array}$ & $\begin{array}{c}5 \\
(5 \%)\end{array}$ \\
\hline 2. & $\begin{array}{l}\text { Do you know that the hospital is legally responsible for all } \\
\text { patient/client losses caused by nurses' negligence? }\end{array}$ & $\begin{array}{c}88 \\
(88 \%)\end{array}$ & $\begin{array}{c}12 \\
(12 \%)\end{array}$ \\
\hline
\end{tabular}

Based on these data, it can be seen that most nurses understand well, 95 people $(95 \%)$ respondents understand that the hospital where they work has an obligation to protect and provide legal assistance to nurses in carrying out their profession in hospitals, only 5 people $(5 \%)$ respondents who do not understand the obligations of this hospital. In the event that the hospital is legally responsible for all patient/client losses incurred due to negligence of nurses, there are 88 people $(88 \%)$ respondents who have understood well, that the hospital is liable to bear client losses caused by negligence caused by nurses in carrying out his profession provides nursing services in hospitals, although there are 12 people (12\%) who do not know about the obligations of this hospital.

This shows that socialization of hospital obligations in protecting and providing legal assistance for nurses in carrying out their profession provides nursing/health services, and bears the loss if there is negligence caused by nurses, it still needs to be done so that nurses at work get peace and comfort so that the services provided to clients/communities will be better.

\section{Conclusion}

In working nurses must be given legal protection to give them peace of mind in providing health/nursing services to the community. Preventive legal protection has been accommodated by the State (Government) in the Health Law, Hospital Law, Health Workers Law, Nursing Law and Minister of Health Regulation Number 4 of 2018. Unfortunately, legal protection for nurses in the above laws and regulations only consists of legal assistance by hospitals in the form of mediation/settlement of disputes outside of other courts and compensation to clients/families due to negligence arising from health/nursing services in hospitals in civil cases. For nurses involved in criminal cases not regulated by these laws and regulations. Nurses hope that there are regulations governing legal assistance for them, especially those relating to suspected criminal acts or negligence of nurses that occur during health/nursing services. Because of the absence of these laws and regulations, the nurse can sometimes throw nurses into bars, even though he has worked according to the nurse's code of ethics, professional standards, service standards and SOP. 


\section{References}

Aceh Journal National Network (AJNN). online. May 9, 2017. Tersangka Malpraktek Divonis Ringan, Keluarga Korban Kecewa (Malpractice Suspects Sentenced to Light, Disappointed Family Victims).

Berita satu. online. April 8, 2015. Dua Dokter, Direktur RSIA, Dan Tiga Perawat Jadi Tersangka Malapraktik (Two Doctors, RSIA Director, and Three Nurses Become Malpractice Suspects).

Decision of the Banyuwangi District Court Number 52/Pid.Sus/2018/PN.Byw.

Endang Wahyati Yustina. 2012. Mengenal Hukum Rumah Sakit (Get to Know Hospital Law). Keni Media. Bandung.

http://www.bppsdmk.kemkes.go.id. Data SDM Kesehatan Yang didayagunakan di Fasilitas Pelayanan Kesehatan (Health HR data utilized in the Health Service Facility), accessed on August 4, 2018.

J. Guwandi. 2004. Hukum Medik (Medical Law). Faculty of Medicine, University of Indonesia. Jakarta.

Julianus Ake. 2003. Malpraktik dalam Keperawatan (Malpractice in Nursing). Penerbit Buku Kedokteran EGC. Jakarta.

Kadarudin and Nilawati Adam, Urgensi Pengesahan Rancangan Undang-Undang Keperawatan Menjadi Sebuah Undang-Undang, Terkait Dengan pelayanan Medis Perawat (The Urgency of Ratifying the Draft Nursing Law Becomes an Act, Related to Nurse Medical services), Jurnal Aktualita Vol. IV, $2^{\text {nd }}$ Edition, April 2012. Kopertis Region IX Sulawesi.

Kompas.com. online. March 8, 2018. Saat di Rumah Sakit, Setya Novanto Dipasangi Jarum Infus untuk Anakanak (While in the hospital, Setya Novanto has Infusion Needles for Children).

Kompas.com. online. March 16, 2018. Pemasangan Infus Anak ke Setya Novanto Langgar Kode Etik Keperawatan (Installation of Children's Infusions to Setya Novanto Violates the Code of Ethics for Nursing).

Law of the Republic of Indonesia Number 36 Year 2009 on Health.

Law of the Republic of Indonesia Number 44 Year 2009, on Hospitals.

Law of the Republic of Indonesia Number 36 Year 2014 on Health Workers.

Law of the Republic of Indonesia Number 38 Year 2014 on Nursing.

M. Fakih. 2012. Aspek Keperdataan Dalam Pelaksanaan Tugas Tenaga Keperawatan Di Bidang Pelayanan Kesehatan Di Propinsi Lampung (Civil Aspects in the Implementation of the Duties of Nursing Personnel in the Field of Health Services in Lampung Province). Dissertation Summary of the Doctoral Program in Legal Science, Faculty of Law, Gadjah Mada University.

Nilawati Adam, Analisis Mekanisme Koping Keluarga Yang Anggota Keluarganya Di Rawat Di Instalasi Rawat darurat Rumah Sakit Umum Ibnu Sina YW UMI Kota Makassar Tahun 2010 (Analysis of Family Coping Mechanisms Which Members of Their Families Are Cared for in Emergency Care Ibnu Sina General Hospital YW UMI Makassar City in 2010), Journal of Health, Vol. II, $1^{\text {st }}$ Edition, March 2012. Kopertis Region IX Sulawesi.

Nilawati Adam. Korelasi Hukum Antara Tujuan Pengaturan Dengan Asas Praktik dalam Undang-Undang Keperawatan (Legal Correlation Between the Purpose of Arrangement with the Principle of Practice in the Nursing Law). Jurnal Hukum Justitia, Vol. II, No. 2 March 2015.

Nilawati Adam. Peranan World Health Organization di Negara Maju dan Negara Berkembang (The Role of the World Health Organization in Developed Countries and Developing Countries). Jurnal Hukum Justitia, Vol. III, No. 1 September 2015. 
Nilawati Adam. National Health Coverage Sebagai Hak Asasi Setiap Warga Negara, Suatu Kajian Hukum Kesehatan (National Health Coverage as A Human Rights for Every Citizen, A Health Law Study). Jurnal Hukum Justitia, Vol. V, No. 1 September 2017.

Nilawati Adam and Maria Ana Liwa. Pelayanan Kesehatan dari Kajian Hukum dan Hak Asasi Manusia (Health Services from the Study of Law and Human Rights), Jurnal Ilmu Hukum “THE JURIS” Vol. II, No. 2, December 2018.

Philipus M. Hadjon. 1987. Perlindungan Hukum Bagi Rakyat di Indonesia (Legal Protection for the People in Indonesia). Bina Ilmu. Surabaya.

PPNI. 2010. Standar Profesi \& Kode Etik Indonesia (Professional Standards \& Indonesian Code of Ethics). Jakarta.

PPNI. 2016. Kode Etik Keperawatan, Lambang Panji PPNI dan Ikrar Keperawatan (Nursing Code of Ethics, PPNI Symbol and Nursing Pledge), Jakarta.

PPNI. 2017. Standar Diagnosis Keperawatan Indonesia Defenisi dan Indikator Diagnostik (Indonesian Definition of Nursing Diagnosis Standards and Diagnostic Indicators). Jakarta.

PPNI. 2017. Pedoman Perilaku Sebagai Penjabaran Kode Etik Keperawatan (Code of Conduct Descriptions as the Nursing Code of Ethics). Jakarta.

PPNI. 2017. Pedoman Penyelesaian Sengketa Etik Keperawatan (Nursing Ethic Dispute Resolution Guidelines). Jakarta.

PPNI. 2018. Standar Intervensi Keperawatan Indonesia Defenisi dan Tindakan Keperawatan (Indonesian Nursing Intervention Standards Definition and Nursing Actions). 2018.

Regulation of the Minister of Health of the Republic of Indonesia Number 4 Year 2018 concerning Hospital Obligations and Patient Obligations.

Salim HS and ES Nurbaya. 2013. Penerapan Teori Hukum Pada Penelitian Disertasi dan Tesis (Application of Legal Theory in Dissertation and Thesis). RajaGrafindo Persada. Jakarta.

SerambiNews.com. online. April 7, 2016. 3 Perawat RS Arun Dinonaktifkan (3 Arun Hospital Nurses Disabled).

SerambiNews.com. online. April 18, 2017. Perawat RS Arun Dituntut Setahun (Arun Hospital Nurse Sued a Year).

SINDOnews. online. April 2, 2015. Dokter RSIA Pinatih Jadi Tersangka Malapraktik (Doctor RSIA Pinatih Becomes a Malpractice Suspect).

Takdir Rahmadi. 2017. Mediasi Penyelesaian Sengketa Melalui Pendekatan Mufakat (Mediation of Dispute Resolution through a Consensus Approach). PT RajaGrafindo Persada. Depok.

The 1945 Constitution of the Republic of Indonesia. 